\title{
Evaluation of Composite Reinforcement on the Fracture Resistance of Teeth with Unsupported Cusps
}

\author{
Evaluación del Reforzamiento con Resina Compuesta sobre la \\ Resistencia a la Fractura de Dientes con Cúspides sin Soporte
}

\author{
Marly Christiènne Capaneli Guimarães Ferreira*; lara Augusta Orsi";

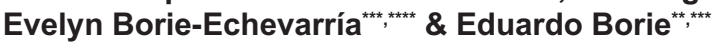

FERREIRA, M. C. C. G.; ORSI, I. A.; BORIE-ECHEVARRÍA, E. \& BORIE, E. Evaluation of composite reinforcement on the fracture resistance of teeth with unsupported cusps. Int. J. Odontostomat., 8(1):133-139, 2014.

SUMMARY: This study evaluated the fracture resistance of maxillary premolars with wide Mesial-Occlusal-Distal (MOD) cavity preparations and unsupported cusps restored by four ways, compared with intact teeth. Thirty five human teeth were divided into five groups: control (G1 - intact teeth) and four experimental groups of MOD-prepared teeth: with buccal (B) and lingual (L) cusps reinforced with composite (Z-250) and restored with silver amalgam (Permite $C)(G 2)$; teeth with $B$ and $L$ cusps reinforced and linked with composite (P-60) and restored with silver amalgam (Permite $C)(G 3)$; teeth restored with composite (Z-250) by incremental fill technique (G4); and teeth with $B$ and $L$ cusps reinforced and linked with composite (P-60) and restored with composite (Z-250) by incremental fill technique (G5). After thermal cycling (500 cycles, $5^{\circ} \mathrm{C}$ to $55^{\circ} \mathrm{C}$ ), fracture resistance was tested in a universal testing machine. Statistical analysis of the results (ANOVA) revealed no significant difference ( $p>0.5$ ) among the groups (G1=157.78Kgf, G2=183.99Kgf, G3=152.53Kgf, G4=182.61 Kgf and $\mathrm{G} 5=155.96 \mathrm{Kgf}$ ). Visual analysis of the teeth tested showed predominance of oblique failure pattern. The four types of restoration evaluated provide fracture resistance with values equivalent to intact teeth in MOD-prepared intact teeth with parallel walls and composite-reinforced cusps.

KEY WORDS: fracture resistance, composite, dental amalgam.

\section{INTRODUCTION}

Loss of structural integrity weakens teeth, making them more susceptible to failure. Cavity preparations significantly decrease fracture resistance, in a way directly proportional to the degree of reduction in dental structure (Vale, 1959; Mondelli et al., 1980; Catovic et al., 1997; Dang et al., 1997; Mondelli et al., 1998). Occlusal loads generate stress within the tooth, in intact teeth these forces are uniformly distributed along the occlusal surface, as well as inside the tooth. However, mesial-occlusal-distal (MOD) cavity preparations alter the stress distribution, resulting in high tensile stresses on the pulpal floor and compressive stresses on the cervical surface (Patras \& Doukoudakis, 2013). Under repetitive occlusal load, the tensile stress may cause cracks that propagate along the failure planes, finally leading to cuspal failure. This mechanism represents progressive fatigue of the brittle tooth tissues (Bell et al., 1982). Complete destruction of the tooth results from the interaction between multiple cracks to cause spalling of sections of the enamel (Keown et al., 2012).

Intact teeth suffer little deformation under occlusal load. However, if the enamel is lost, the dentin characteristics become preponderant to cuspal performance. Although enamel and dentin are organically joined, their responses to occlusal load differ, due to their different elastic modulus (Goel et al., 1990). Consequently, the maintenance of maximum dental structure, especially interaxial dentin, is very important (Caron et al., 1993).

* Private practice, Franca, São Paulo, Brazil.

* Department of Dental Materials and Prosthodontics, School of Dentistry of Ribeirão Preto, University of São Paulo, Ribeirão Preto, São Paulo, Brazil.

*** CIMOFIR Research Center, Dental School, Dental School, Universidad de La Frontera, Temuco, Chile.

Univ* Universidad Mayor, Temuco, Chile. 
The technological evolution of enamel and dentin adhesives allowed conservative dental cavity preparations, contrarily to Black's principles, which advise complete removal of unsupported enamel.

The procedure of enamel etching associated to Bowen's composite broadened the indications for composite restorations, particularly in posterior teeth. Denehy \& Torney (1976) were the first to suggest the use of adhesive materials for dental reinforcement. Silver amalgam, used since 1826, cannot reinforce dental structure because it does not adhere to these tissues. Adhesive materials provide reinforcement to the remaining dental structures (Denehy \& Torney; Breschi et al., 2008). Therefore, cusps undermined by carious lesions can be reinforced and/or linked with composite, in order to decrease deformation under occlusal loads. Even though nowadays composites are widely used, silver amalgam is still applied in several clinical situations.

This study assessed the effect of composite reinforcement and linking of $B$ and $L$ cusps on the fracture resistance of MODprepared maxillary premolars with unsupported cusps restored with different material combinations, compared to intact teeth.

\section{MATERIAL AND METHOD}

This study was approved by the Ethics Committee of Ribeirão Preto Dental School, University of São Paulo (Protocol Number 2002.1.453.58.0).

Thirty five human maxillary premolars, non-carious or minimally restored (occlusal restorations), were mounted with their roots imbedded in self-cured acrylic resin (Dencôr, Clássico Ltda, São Paulo, Brazil) in polystyrene resin cylinders (Tigre S.A. Tubos e Conexões, Joinville, Brazil) $25 \mathrm{~mm}$ in diameter and $12 \mathrm{~mm}$ in height, exposing $2 \mathrm{~mm}$ of the root surface below the cementumenamel junction. Teeth were randomly divided into five groups with 7 specimens each $(n=7)$ : one control group and four experimental groups, according to the restorative procedure used.

Teeth in Group 1 (controls) were kept in distilled water while teeth in the experimental groups received Mesial-Occlusal-

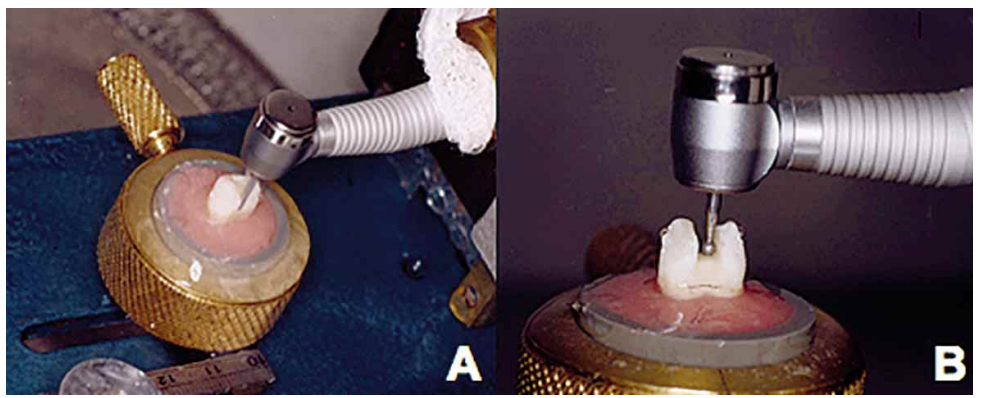

Distal (MOD) cavity preparations. Crowns were measured with a digital pachymeter (model SC-6, Mitutoyo Corporation, Myasaki, Japan) in order to determine intercuspal distances and to limit the occlusal and proximal boxes, standardizing the MOD preparations. Specimens were placed in an apparatus containing a dispositive, to which a high-speed water-cooled handpiece was attached (Fig. 1). This device allowed accurate movements of the samples and of the handpiece, resulting in cavity walls with standard inclination, depth and width, measured by rulers (Fig. 2).

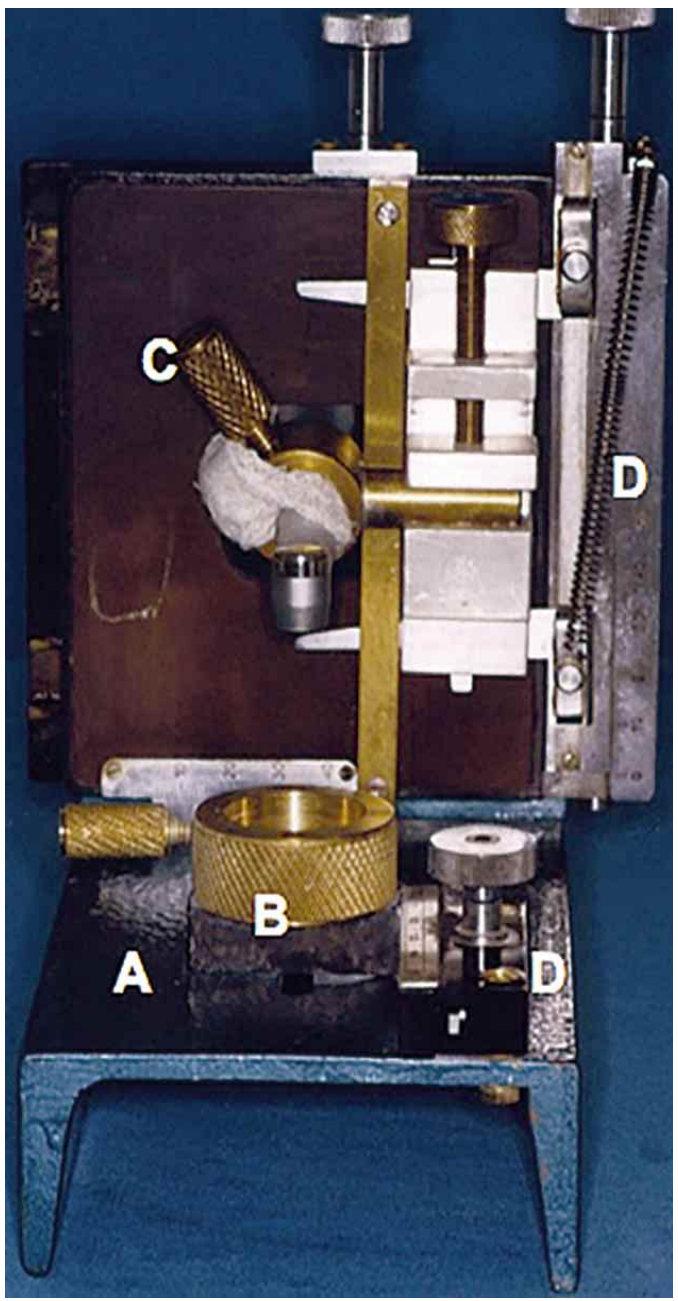

Fig. 1. Device for tooth preparation. A. Metallic base; B. Samples place; C. Vertical device; D. Millimetric rules for standardization of tooth preparations.

Fig. 2. A and B. Executing tooth preparation. 
The MOD cavities with parallel walls and proximal boxes were prepared with cylindrical diamond bur (\# 4102, KG Sorensen, Barueri, SP, Brazil). Preparations involved one half of the intercuspal distance width, the gingival wall was situated $1.0 \mathrm{~mm}$ above the cementum-enamel junction, and the pulpal floor was $2.0 \mathrm{~mm}$ above the same junction for smaller teeth and $2.5 \mathrm{~mm}$ for larger ones to avoid pulpal exposition. The gingival wall width followed the diameter of the cylindrical bur $(1.4 \mathrm{~mm})$. In order to weaken the dental structure, dentin underneath the buccal and lingual cusps was removed using a spherical diamond bur (\# 1016, KG Sorensen, Barueri, SP, Brazil) of the $1.8 \mathrm{~mm}$ diameter. Experimental specimens were then kept in distilled water at room temperature $\left(25^{\circ} \mathrm{C}\right)$ until restored, one week later. In Group 2, enamel and dentin under the buccal (B) and lingual (L) cusps were etched with $37 \%$ phosphoric acid (3M, Sumaré,SP, Brazil) for 15 seconds, bonded with 2 layers of SingleBond adhesive (3M, Sumaré, SP, Brazil) according to manufacturer's instructions, and filled with Z-250 composite (3M, Sumaré, SP, Brazil). Next, the MOD cavities were restored with Permite $C$ silver amalgam (SDI, Bayswater, Australia) following the conventional technique. The silver amalgam was sculpted and teeth were placed on an apparatus containing a steel sphere $(5 \mathrm{~mm}$ diameter) that contacted the cusps and restorations simultaneously, in order to simulate clinical conditions (Fig. 3). Group 3: enamel and dentin underneath the $B$ and $L$ cusps were etched with $37 \%$ phosphoric acid (3M) for 15 seconds, SingleBond adhesive (3M) was applied, and these walls were restored with P-60 (3M, Sumaré, SP, Brazil). Next, buccal and lingual reinforced cusps were linked with composite (P-60) in three increments, after placing a specially designed cast metallic matrix within the limits of the occlusal box. After that, MOD cavities were restored with silver amalgam (Permite $\mathrm{C}$ ). The teeth were then conducted to the previously described sphere apparatus (Fig. 4). Group 4: internal surfaces were etched with $37 \%$ phosphoric acid (3M) for 15 seconds, SingleBond adhesive $(3 \mathrm{M})$ was applied in two layers, and cavities were restored with Z-250 composite (3M, Sumaré, SP, Brazil), starting at the unsupported cusps, following the four-increments technique (Wieczkowski et al., 1988). Teeth were then placed on the sphere apparatus. Group 5: all preparation surfaces were etched with $37 \%$ phosphoric acid for 15 seconds, received SingleBond in two layers, and the weakened cusps were linked with P-60 composite, in three increments, using the previously described matrix. Next, teeth were restored with four increments of Z-250 composite (incremental technique). The teeth were then conducted to the sphere apparatus.

The four types of restorations in a buccal-lingual section are represented in Figure 5. After that, specimens were stored in distilled water at room temperature for two days, until restorations were polished/finished.

Specimens were returned to the container with tap water at room temperature for four days to prevent dehydration. Teeth

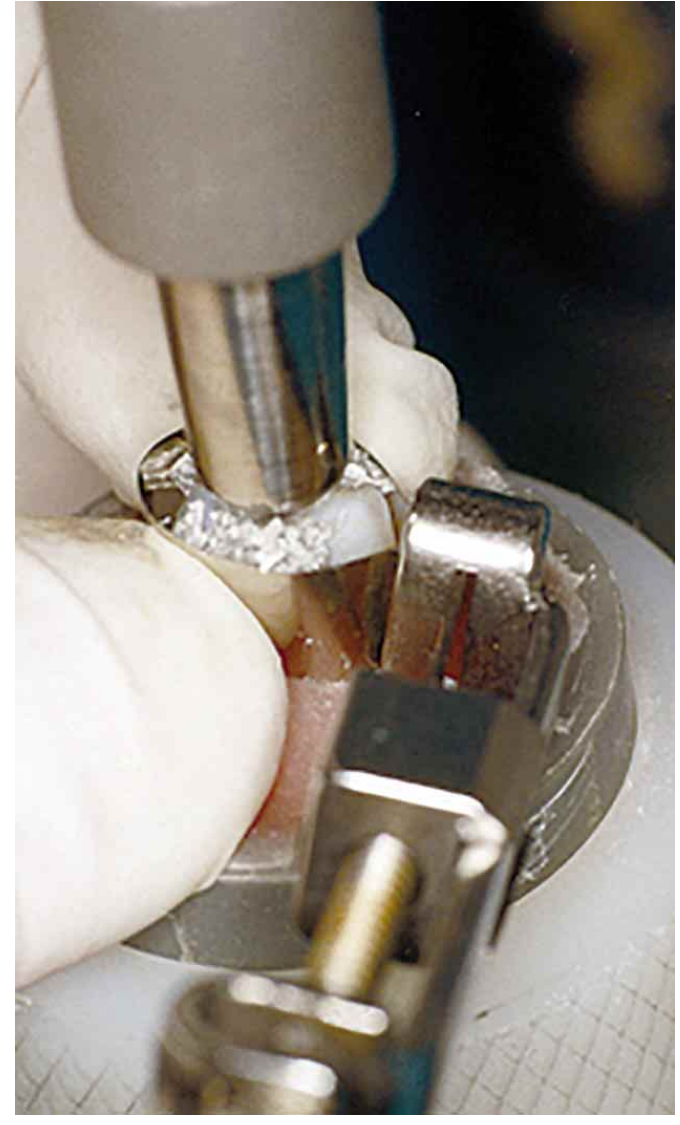

Fig. 3. Steel sphere in contact with dental restoration and cusps.

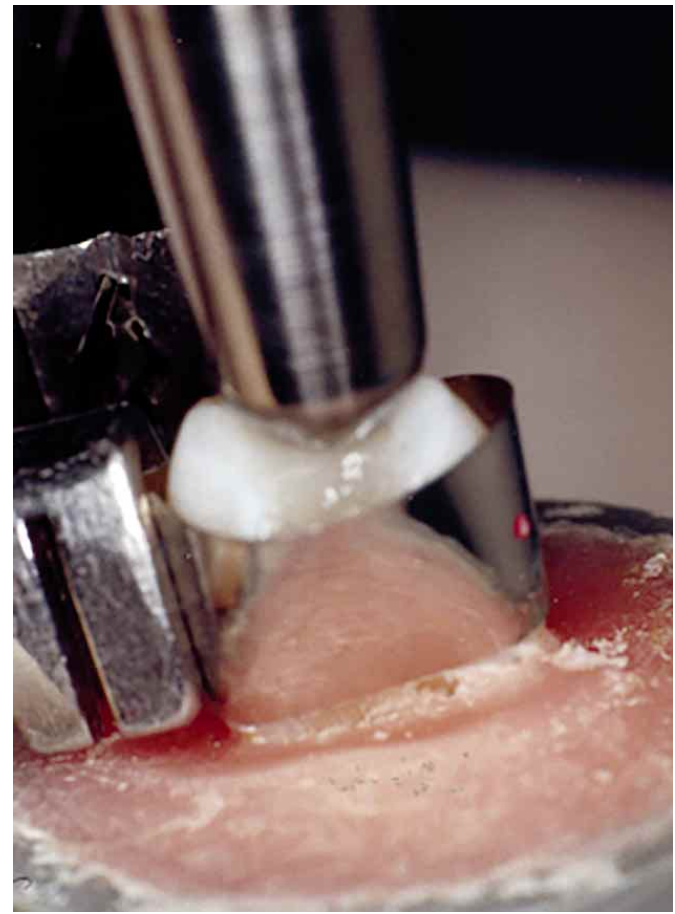

Fig. 4. Sample attached to device with sphere in position. 


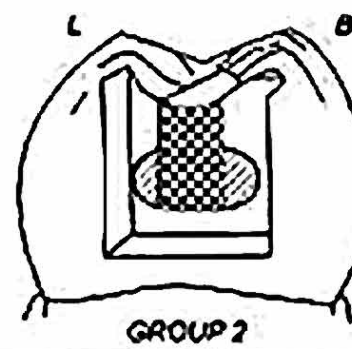

GROUP?

88:

Amober (parria)

carposice R.25cs

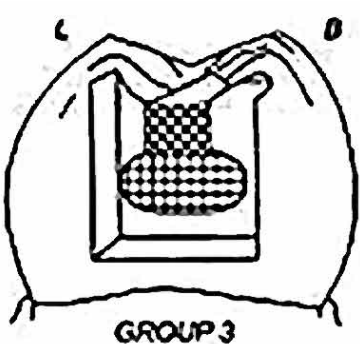

GROP3
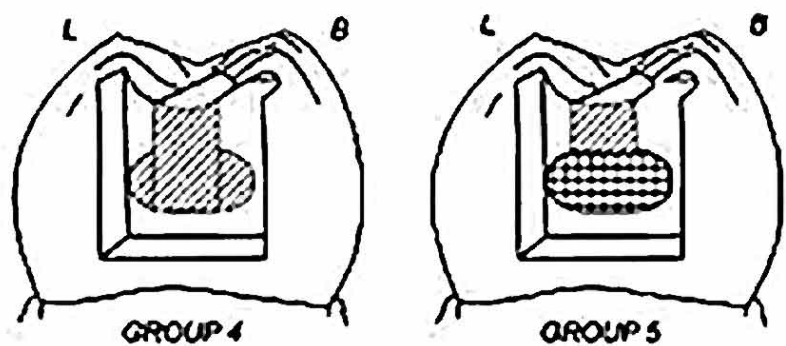

Fig. 5. Four types of restorations in a buccal-lingual section.

were then subjected to thermal cycling (Ética Equipamentos Científicos S.A., São Paulo, Brazil), with 500 cycles from $5^{\circ} \mathrm{C}$ to $55^{\circ} \mathrm{C}$ (ISO/TR 11405: $1994(\mathrm{E})$ ). After seven days of storage in water at $37^{\circ} \mathrm{C}$, specimens were tested for resistance using a universal testing machine (model MEM-200, EMIC
Equipamentos e Sistemas de Ensaio Ltda, São José dos Pinhais, Brazil). A 500Kgf load was applied and a 5-mm-diameter steel sphere plunger contacted the restorations and buccal/lingual cusps of the tested teeth at a crosshead speed of $0.5 \mathrm{~mm} /$ minute, until fracture occurred (Fig. 6)

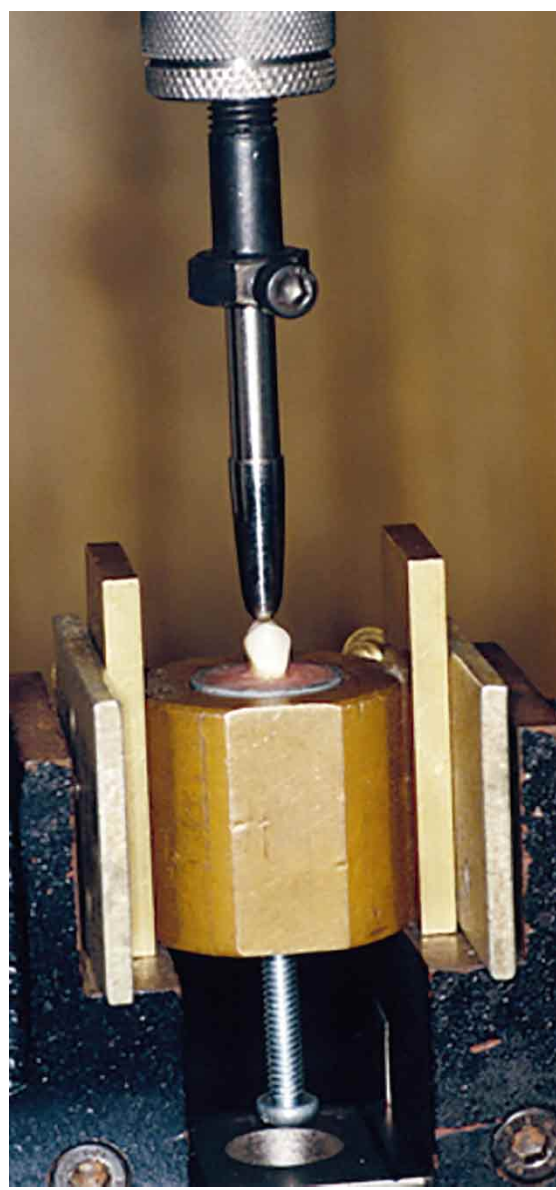

Fig. 6. Sample placed in a universal testing machine.

\section{RESULTS}

Preliminary statistical analysis showed that the sample distribution was normal and homogeneous, thereby allowing the use of parametric tests. To compare the maxillary premolars with unsupported cusps restored with different material combinations, compared to intact teeth, one-way analysis of variance was performed (Table I).

The variation factor (type of restoration) did not show significant difference among the groups ( $p>0.5$ ): no statistically significant differences were observed among the mean values of fracture resistance of MODprepared teeth restored with different materials compared to one another, neither between intact and restored teeth (Table II). The fracture pattern observed by visual analysis was predominantly oblique, involving a single cusp (G1=100\%; G2=43\%; G3=100\%; G4=86\%; G5=71\%).

Table I. Results of the Analysis of Variance.

\begin{tabular}{lccccc}
\hline Source of & Sum of & D.F. & Mean & $(\mathbf{F})$ & Prob. $\left(\mathbf{H}_{\mathbf{0}}\right)$ \\
\hline Restorations & 6633.9463 & 4 & 1658.4866 & 1.26 & $30.743 \%$ \\
Error & 39524.1172 & 30 & 1317.4706 & & \\
Total & 46158.0625 & 34 & & & \\
\hline
\end{tabular}

$\mathrm{ns}=$ no significant difference

Table II. Mean values of the load and standard deviation (Kgf).

\begin{tabular}{lc}
\hline Group & Mean (SD) \\
\hline Control & $157,78( \pm 24.58)$ \\
Amalgam & $183.99( \pm 52.47)$ \\
Amalgam/linked cusps & $152.53( \pm 27.53)$ \\
Composite & $182,61( \pm 34.53)$ \\
Composite/linked cusps & $155.96( \pm 35.77)$ \\
\hline
\end{tabular}




\section{DISCUSSION}

The fracture resistance tests revealed that the type of restorative material does not affect resistance to fracture of teeth with wide MOD cavities (half intercuspal distance width) (Marchan et al., 2009). This type of cavity preparation, wide and deep, strongly weakens the dental structure (Joynt et al., 1987; Reeh et al., 1987; Caron et al.; Panitvisai \& Messer, 1995; Mondelli et al., 1998; Khera et al., 1999; Jantarat et al., 2001; de Freitas et al., 2002).

Regarding restored teeth (Groups 2-5), the results of the present study are in agreement with some researches of Joynt et al., Reeh et al., Panitvisai \& Messer, Khera et al. and Roberts et al. (2008), who observed no differences between silver amalgam and composite restorations in the fracture resistance of premolars. However, the results disagree with others researchers (Sheth et al., 1988; Goel et al.; Boyer \& Roth, 1994; Ragauska et al., 2008), who reported significant difference between teeth restored with silver amalgam and those restored with composite. The absence of statistical difference between composite and silver amalgam in the present study may be due to the fact that teeth restored with silver amalgam (G2 and G3) also had their cusps reinforced with composite. This may have increased their resistance to fracture (Denehy \& Torney).

Joynt et al., Reeh et al., Panitvisai \& Messer and Khera et al. observed that teeth restored with silver amalgam or composite had similar fracture resistance values, but found significant difference between intact and restored teeth, as well as between intact teeth and those with MOD preparations, differing from this study's results. The high mean resistance values for intact teeth found in the present study are similar Mondelli et al. (1980) research, which used $140.80 \mathrm{Kgf}$ and similar methodology.

Although expected, differences among the restorative materials and combinations tested, as well as between restored and intact teeth, were not detected. The four restorative combinations tested resulted in resistance values similar to intact teeth.

The composite was able to recover stiffness to values found in intact teeth, while silver amalgam was not. Progressive structural fatigue causes loss of adhesion between dental tissues and restorative material. Therefore, teeth restored with composite behave similarly to those restored with silver amalgam, when strain tests are applied (Reeh et al.). This may explain the lack of difference in fracture resistance between composite-restored and silver amalgam-restored teeth in the present study. Additionally, the dental reinforcement provided by composite is directly proportional to the resistance and longevity of the adhesive bonding (Pilo et al., 1998).

The procedure of linking cusps with composite has been suggested to prevent cuspal deflection under masticatory load, preventing changes in internal stress location, crack growth, and their consequences (Roberts et al.). Nevertheless, linking cusps with composite does not increase fracture resistance.

The oblique fracture patterns observed in the present study, both in intact teeth and in teeth restored with different materials, are in agreement with Mackenzie et al. (1986), who observed that most fractures in composite-restored teeth are oblique. The use of bonding adhesives led to oblique fracture involving a single cusp, while teeth with silver amalgam restorations showed fracture at the cavity preparation (Eackle et al., 1992). Is important to point out that a low average percentage of microleakage appeared at the amalgamcomposite interface $(7 \%)$ in restoring extensive Class I preparations (Franchi et al., 1999). Oblique fractures are clinically favorable, since they allow direct or indirect restorations (Hagge \& Rector, 1993), while vertical fractures are extremely unfavorable, usually leading to extraction of the tooth. In the present study, most dental fractures in all groups were oblique, with favorable prognosis for future restoration.

\section{CONCLUSIÖN}

Based on the results from the present study, it may be concluded that the four types of restoration evaluated provide fracture resistance to values equivalent to intact teeth in MOD-prepared teeth with parallel walls and composite-reinforced cusps. Moreover, the fractures observed were predominantly oblique, leading to a favorable prognosis for future restorations, a situation also comparable to intact teeth. Accordingly, prior to restoring teeth with silver amalgam, dentists should consider the extension of dental decay and reinforce unsupported cusps with composite. 
FERREIRA, M. C. C. G.; ORSI, I. A.; BORIE-ECHEVARRÍA, E. \& BORIE, E. Evaluación del reforzamiento con resina compuesta sobre la resistencia a la fractura de dientes con cúspides sin soporte. Int. J. Odontostomat., 8(1):133-139, 2014.

RESUMEN: Se evaluó la resistencia a la fractura de los premolares maxilares con preparaciones amplias de cavidades Mesio-Ocluso-Distal (MOD) y cúspides sin soporte restauradas por medio de cuatro formas, en comparación con dientes intactos. Treinta y cinco dientes humanos se dividieron en cinco grupos: control (G1 - dientes intactos) y cuatro grupos experimentales preparados con cavidades MOD: con cúspides bucales (B) y linguales (L) reforzadas con resina compuesta (Z-250) y restaurada con amalgama de plata (Permite C) (G2); dientes concúspides B y L reforzadas y unidas con composite (P-60) y restaurado con amalgama de plata (Permite $C)(G 3)$; dientes restaurados con composite (Z-250) a través de la técnica incremental (G4), y dientes con cúspides B y L reforzadas y unidas con resina compuesta (P-60) y restauradas con composite (Z-250) mediante la técnica incremental (G5). Después del ciclado térmico $\left(500\right.$ ciclos, $5^{\circ} \mathrm{C}$ a $55^{\circ} \mathrm{C}$ ), la resistencia a la fractura fue probada en una máquina de ensayo universal. El análisis estadístico de los resultados (ANOVA) no reveló diferencias significativas ( $p>0,5$ ) entre los grupos ( $\mathrm{G} 1=157,78 \mathrm{Kgf}$, $\mathrm{G} 2=183,99 \mathrm{Kgf}, \mathrm{G} 3=152,53 \mathrm{Kgf}$, G4 = 182,61 Kgf y G5 = 155,96 Kgf). El análisis visual de los dientes probados mostró un predominio de patrón de falla oblicua. Los cuatro tipos de restauración evaluados proporcionaron resistencia a fractura con valores equivalentes a los dientes intactos con preparaciones MOD, paredes paralelas y cúspides reforzadas con resina compuesta.

PALABRAS CLAVE: resistencia a la fractura, composite, amalgama dental.

\section{REFERENCES}

Bell, J. G.; Smith, M. C. \& de Pont, J. J. Cuspal failures of MOD restored teeth. Aust. Dent. J., 27(5):283-7, 1982.

Breschi, L.; Mazzoni, A.; Ruggeri, A.; Cadenaro, M.; Di Lenarda, R. \& De Stefano Dorigo, E. Dental adhesion review: aging and stability of the bonded interface. Dent. Mater., 24(1):90-101, 2008.

Boyer, D. B. \& Roth, L. Fracture resistance of teeth with bonded amalgams. Am. J. Dent., 7(2):91-4, 1994.

Caron, G. A.; Murchinson, D. F.; Cohen, R. B. \& Broome, J. C. Resistance to fracture of teeth with various preparations for amalgam. J. Dent., 24(6):407-10, 1993.

Catovic, A.; Kraljevic, K.; Jerolimov, V.; Celebic, A.; Kovacicek, F. \& Valentic-Peruzovic, M. The response of human premolars to cyclic loading. J. Oral Rehabil., 24(4):320-4, 1997.

Dang, N.; Meshram, G. K. \& Mittal, R. K. Effects of designs of class 2 preparations on resistance of teeth to fracture. Indian J. Dent. Res., 8(3):90-4, 1997.

de Freitas, C. R.; Miranda, M. I.; Andrade, M. F.; Flores, V. L.; Vaz, L. G. \& Guimarães, C. Resistance to maxillary premolar fracture after restoration II preparations with resin composite or ceromer. Quintessence Int., 33(8):589-94, 2002.

Denehy, G. E. \& Torney, D. L. Internal enamel reinforcement through micromechanical bonding. J. Prosthet. Dent., 36(2):171-5, 1976.
Eakle, W. S.; Staninec, M. \& Lacy, A. M. Effect of bonded amalgam on the fracture resistance of teeth. $J$. Prosthet. Dent., 68(2):257-60, 1992.

Franchi, M.; Breschi, L. \& Ruggeri, O. Cusp fracture resistance in composite-amalgam combined restorations. J. Dent., 27(1):47-52, 1999.

Goel, V. K.; Khera, S. C. \& Singh, K. Clinical implications of response of enamel and dentine to masticatory loads. J. Prosthet. Dent., 64(4):446-54, 1990.

Hagge, M. S. \& Rector, T. M. Review of periodontal considerations and surgical retraction techniques for operative dentistry. Oper. Dent., 18(5):179-86, 1993.

Jantarat, J.; Palamara, J. E. \& Messer, H. H. An investigation of cuspal deformation and delayed recovery after occlusal loading. J. Dent., 29(5):36370, 2001.

Joynt, R. B.; Wieczkowski, G. Jr.; Klockowski, R. \& Davis, E. L. Effects of composite restorations on resistance to cuspal fracture in posterior teeth. J. Prosthet. Dent., 57(4):431-35, 1987.

Keown, A. J.; Lee, J. J. \& Bush, M. B. Fracture behavior of human molars. J. Mater. Sci. Mater. Med., 23(12):2847-56, 2012.

Khera, S. C.; Goel, V. K.; Chen, R. C. \& Gurusami, S. A. Parameters of MOD cavity preparations: a 3-D FEM study, Part II. Oper. Dent., 16(2):42-54, 1999. 
Mackenzie, D. F. The reinforcing effect of mesial-occlusodistal acid-etch composite restorations on weakened posterior teeth. Br. Dent. J., 161(11):410-4, 1986.

Marchan, S. M.; Coldero, L.; White, D.; Smiyh, W. A. \& Rafeeki, R. N. Cusp fracture resistance of maxillary premolars restored with the bonded amalgam technique using various luting agents. Int. J. Dent., 2009:946830, 2009.

Mondelli, J.; Steagall, L.; Ishikiriama, A.; de Lima Navarro, M. F. \& Soares, F. B. Fracture strength of human teeth with cavity preparations. J. Prosthet. Dent., 43(4):41922, 1980.

Mondelli, R. F.; Barbosa, W. F.; Mondelli, J.; Franco, E. B. \& Carvalho, R. M. Fracture strength of weakened human premolars restored with amalgam and without cusp coverage. Am. J. Dent., 11(4):181-4, 1998.

Panitvisai, P. \& Messer, H. H. Cuspal deflection in molars in relation to endodontic and restorative procedures. $J$. Endod., 21(2):57-61, 1995

Patras, M. \& Doukoudakis, S. Class II composite restorations and proximal concavities: clinical implications and management. Oper. Dent., 38(2):119-24, 2013.

Pilo, R.; Brosh, T. \& Chweidan, H. Cusp reinforcement by bonding of amalgam restorations. J. Dent., 26(5-6):467$72,1998$.

Ragauska, A.; Apse, P.; Kasjanovs, V. \& Berzina-Cimdina, L. Influence of ceramic inlays and composite fillings on fracture resistance of premolars in vitro. Stomatologija, 10(4):121-6, 2008.

Reeh, E. S.; Douglas, W. H. \& Messer H. H. Stiffness of endodontically-treated teeth related to restoration technique. J. Dent. Res., 68(11):1540-4, 1989.

Roberts, H. W.; Vandewalle, K. S.; Charlton, D. G. \& Berzins, D. W. Fracture resistance of amalgam/glasspolyalkenoate open sandwich Class II restorations: An in vitro study. J. Dent., 36(11): 873-7, 2008.

Sheth, J. J.; Fuller, J. L. \& Jensen, M. E. Cuspal deformation and fracture resistance of teeth with dentin adhesives and composites. J. Prosthet. Dent., 60(5):560-9, 1988.

Vale, W. A. Cavity preparation and further thoughts on high speed. Brit. Dent. J., 107(11):333-40, 1959.

Wieczkowski, Jr. G.; Joynt, R. B.; Klockowski, R. \& Davis, E. L. Effects of incremental versus bulk fill technique on resistance to cuspal fracture of teeth restored with posterior composites. J. Prosthet. Dent., 60(3):283-7, 1988.
Correspondence to:

Profa. Dra. lara Augusta Orsi

Department of Dental Materials and Prosthodontics

Ribeirão Preto Dental School

University of São Paulo

Avenida do Café S/N, Monte Alegre, 14040-904

Ribeirão Preto, SP

BRAZIL

Tel: +55-16-3602-4796

Email: iaraorsi@forp.usp.br

Received: 09-10-2013

Accepted: 31-01-2014 